\title{
The Effect of Concentration and Time Interval of Kinetin Application on The Growth of Daun Duduk (Desmodium triquetrum L.) Seeds
}

\author{
Asty Pratista Magdhalena ${ }^{1}$, Bambang Pujiasmanto ${ }^{1,2}$, Sulandjari ${ }^{1,2}$, and Ahmad Yunus ${ }^{1,2^{*}}$ \\ ${ }^{1}$ Department of Agrotechnology, Faculty of Agriculture, Universitas Sebelas Maret, J1. Ir. Sutami 36A \\ Kentingan Jebres Surakarta 57126, Indonesia \\ ${ }^{2}$ Center for Biotechnology and Biodiversity Research and Development, Institute of Research and Community \\ Services, Universitas Sebelas Maret, J1. Ir. Sutami 36A Kentingan Jebres Surakarta 57126, Indonesia
}

*Corresponding author: yunus.uns7@yahoo.com

\begin{abstract}
Daun duduk (Desmodium triquetrum L.) is a medicinal plant that has the power to treat hemorrhoids, but has not been widely cultivated. This research was conducted to obtain the right concentration and time interval of kinetin application to increase the growth of Daun duduk seedlings. This research was conducted from November 2019 until March 2020 at the Screen House, Faculty of Agriculture, UNS. The factors of the experiment were concentration of kinetin $(0 \mathrm{ppm}, 10 \mathrm{ppm}, 20 \mathrm{ppm}$ and $30 \mathrm{ppm})$ and the time interval of application (once every three months, once every 1.5 months and once a month). The parameters observed in this study were plant height, stem diameter, number of leaves, number of branches, number of roots, root length, fresh stover and dry stover. The results showed that the single factor of kinetin concentration could increase plant height, stem diameter, number of leaves, number of branches and dry stover. Meanwhile, the time interval for application and the interaction between the two factors did not have any significant effect. The most effective kinetin concentration in increasing the growth of Daun duduk was $30 \mathrm{ppm}$.
\end{abstract}

Keywords: growth regulators; herbal medicines; plant height.

Cite this as: Magdhalena, A. P., Pujiasmanto, B., Sulandjari, and Yunus, A. (2021). The Effect of Concentration and Time Interval of Kinetin Application on The Growth of Daun Duduk (Desmodium triquetrum L.) Seeds. Journal of Biodiversity and Biotechnology. 1(1), 29-37. doi: http://dx.doi.org/10.20961/jbb.v1i1.50418.

\section{Introduction}

Indonesia is a country that has a tropical climate, so that the level of biodiversity is very high, one of which is medicinal plants. Nowadays, many people are returning to using herbal medicine as an alternative treatment. According to Ismail (1), the factor that encourages people to look for alternatives in reducing chemical drugs is that herbal medicines are considered more economical and have fewer side effects.

Central Bureau of Statistics (BPS) data (2) states that the export value of medicinal plants from Indonesia in 2018 reached USD 601.2 million; which makes Indonesia potential in medicinal plants development. However, not many people have cultivated medicinal plants. According to Salim and Ernawati (3), medicinal plants have not been widely cultivated. One of the reasons is that it is difficult to maintain, especially those from the forests. Wild plants grow well in ther habitats because of the optimum environmental condition.

Daun duduk is a medicinal plant that grows and develops in Indonesia. Daun duduk is efficacious as a hemorrhoid medicine. Besides that, they can also be used to cure several diseases, including dysentery, fever, prostate, obesity and diabetes. Daun duduk can be used, especially the leaves, as herbal medicine. Secondary metabolites produced by Daun duduk are saponins, flavonoids, glycosides, trigonelline, tannins, phenolics, alkaloids and terpenoids.

Daun duduk has not been widely cultivated in general, and this is due to a lack of information about the properties and good cultivation practice of this plant. Daun duduk 
still comes from their natural habitat; and the harvest must be limited to maintain forest sustainability; hence, Daun duduk cultivation is necessary. Karmawati et al. (1996) in Mirza et al. (4) stated that the cultivation of medicinal plants in Indonesia faces obstacles, namely fluctuations in production caused by not implementing good cultivation. Propagation of Daun duduk plants is done generatively, namely using seeds. One of the growth regulators that can affect plant growth is kinetin. Kinetin is a cytokinin group that functions to regulate cell division and morphogenesis (5). The purpose of this study was to determine the kinetin concentration and the right time to increase the growth of Daun duduk seedlings. In addition, this research is also intended to add information about the excellent cultivation of Daun duduk (1).

\section{Material and Methods}

This expertiment was conducted from November 2019 to March 2020 at the Screen House, Faculty of Agriculture, Sebelas Maret University. The materials used in this study, the seeds of Daun duduk, were obtained from the Balai Besar Penelitian dan Pengembangan Tanaman Obat dan Obat Tradisional (B2P2TOOT) Tawangmangu, E. Merck trademark kinetin (98\% kinetin) (0 ppm. 10 ppm. 20 pp. 30 ppm), andosol soil, roasted husks and cow manure.

This research used a factorial Completely Randomized Design (CRD), which consisted of two factors. The first factor was the kinetin concentration consisting of 4 levels, namely $\mathrm{K} 0$ (0 ppm), K1 (10 ppm), K2 (20 ppm) and K3 (30 $\mathrm{ppm})$. The second factor was the time interval of administration consisting of 3 levels, namely W1 (once every three months), W2 (once every 1.5 months) and W3 (once a month) for three months of observation. The variables observed in this study were plant height, stem diameter, number of leaves, number of branches, number of roots, length of roots, fresh and dry stover.

\section{Results and Discussion}

General conditions of the research

The research location was in the Screen House, Faculty of Agriculture, Sebelas Maret University, Surakarta. The geographic location of the research location is $7^{\circ} 33^{\prime} 39.5$ "South Latitude and $110^{\circ} 51^{\prime} 31.4^{\prime}$ East Longitude is at an altitude of 95 meters above sea level and has an average temperature of $26.4^{\circ} \mathrm{C}-37.8^{\circ} \mathrm{C}$ with air humidity $37 \%-70 \%$.

This research used andosol soil type growing media. Andosol soil came from volcanic materials found in areas around volcanoes and are known as fertile soils compared to other soil types. Andosol soil has the characteristics of a dark brownish color, especially in humus horizons, has high levels of organic matter, looks loose, has crumbly soil structure, and feels slippery when held (6). The pests found at the study sites were grasshoppers (Atractomorpha crenulata) and urethens (Lepidiota stigma).

\section{Plant height}

Height is one of the parameters in plant growth, where the plant cell divides so that the plant will increase in length. Following Hakim et al. (1986) in Haryadi et al. (7), the event of cell division and extension dominated by the tip of the plant shoot will cause an increase in the size of a plant.

Table 1. Effect of kinetin concentration and time interval on the growth of daun duduk

\begin{tabular}{lccccc}
\hline Treatment & Height & Stem diameter & $\begin{array}{c}\text { Number of } \\
\text { leaves }\end{array}$ & $\begin{array}{c}\text { Number of } \\
\text { branches }\end{array}$ & Dry stover \\
\hline K0 (control) & $36.08^{\mathrm{a}}$ & $4.04^{\mathrm{a}}$ & $32.89^{\mathrm{a}}$ & $9.89^{\mathrm{a}}$ & $5.30^{\mathrm{a}}$ \\
K1 $(10 \mathrm{ppm})$ & $38.58^{\mathrm{a}, \mathrm{b}}$ & $4.06^{\mathrm{a}}$ & $36.11^{\mathrm{a}}$ & $12.67^{\mathrm{a}}$ & $6.62^{\mathrm{a}}$ \\
K2 $(20 \mathrm{ppm})$ & $38.50^{\mathrm{a}, \mathrm{b}}$ & $4.27^{\mathrm{a}, \mathrm{b}}$ & $38.67^{\mathrm{a}, \mathrm{b}}$ & $12.67^{\mathrm{a}}$ & $7.45^{\mathrm{a}, \mathrm{b}}$ \\
K3 (30 ppm) & $43.29^{\mathrm{b}}$ & $4.61^{\mathrm{b}}$ & $44.56^{\mathrm{b}}$ & $16.44^{\mathrm{b}}$ & $9.78^{\mathrm{b}}$ \\
W1 (once every three & $39.27^{\mathrm{a}}$ & $4.25^{\mathrm{a}}$ & $38.67^{\mathrm{a}}$ & $13.17^{\mathrm{a}}$ & $7.38^{\mathrm{a}}$ \\
months) & & & & \\
W2 (once every 1.5 months) & $40.32^{\mathrm{a}}$ & $4.33^{\mathrm{a}}$ & $38.75^{\mathrm{a}}$ & $12.83^{\mathrm{a}}$ & $8.10^{\mathrm{a}}$ \\
W3 (once a month) & $37.73^{\mathrm{a}}$ & $4.15^{\mathrm{a}}$ & $36.75^{\mathrm{a}}$ & $12.75^{\mathrm{a}}$ & $6.38^{\mathrm{a}}$ \\
\hline
\end{tabular}

${ }_{\mathrm{a}, \mathrm{b}}$ The numbers followed by the same letter in each treatment show no significant effect $(\mathrm{P}<5 \%)$

The results of the ANOVA analysis test with a level of $5 \%$ indicated that a single treatment of kinetin concentration has a significant effect on the plant height of Daun duduk. In contrast, the treatment interval between kinetin administration and the 
interaction between the two treatment factors did not significantly affect plant height parameters. Table 1 shows that the $\mathrm{K} 3$ treatment $(30 \mathrm{ppm})$ was the best in this study after the 5\% DMRT difference test was carried out; an average of 43.29 was obtained. K3 treatment (30 ppm) was significantly different compared to K0 treatment (control), which was 36.08 on average. This is presumably because the kinetin concentration given was sufficient to stimulate the height growth of Daun duduk. Kinetin can play a role in shoot growth, when shoot growth is good, it will affect the size of the plant. Cytokinins play a positive regulatory role in shoot development and a negative regulatory role in root development. Cytokinins move acropetally through the xylem and systemically through the phloem. Following the research results of Bakar et al. (8), the use of kinetin with a concentration of $3 \mathrm{ppm}$ showed a significant effect on plant height Dendrobium. The average plant height at a concentration of $3 \mathrm{ppm}$ was 1.510 , then the control treatment of 1.043. Treatment K1 (10 $\mathrm{ppm})$ and $\mathrm{K} 2(20 \mathrm{ppm})$ did not show significantly different results compared to treatment K0 (control). This was presumably because the treatment of $\mathrm{K} 1(10 \mathrm{ppm})$ and $\mathrm{K} 2$ (20 ppm) were still inaccurate so that it did not give any natural effect. Growth regulators can positively influence growth and development, influenced by several factors, one of which is the concentration (9).

\section{Stem diameter}

Stem diameter width that is balanced with the height of a plant will make the plant stand firm to support the growth and development of the plant.

The results of the ANOVA analysis test with a level of $5 \%$ can be seen that the time interval for giving kinetin and the interaction between the concentration and the time interval application of kinetin did not have a significant effect on the stem diameter of Daun duduk. However, in a single treatment, the kinetin concentration significantly affected the stem diameter of Daun duduk, then continued with the DMRT difference test of 5\%. Table 2 showed that the best treatment was found in $\mathrm{K} 3$ treatment $(30 \mathrm{ppm})$ with an average of 4.61 . The results of $\mathrm{K} 3$ treatment $(30 \mathrm{ppm})$ were significantly different compared to K0 treatment (control), with on average of 4.04. This was presumably because the $\mathrm{K} 3$ treatment $(30 \mathrm{ppm})$ was considered to have met the right concentration in stimulating cell division so that it can stimulate plant diameter enlargement. Trisna et al. (10) explained that growth regulators quickly diffuse into the plant body and strengthen and enlarge the stems. Following the research results of Fatima and Bano (1998) in Naeem et al. (5), an expansion in rod diameter was seen after kinetin application. Treatment K1 (10 ppm) obtained an average of 4.06, significantly different when compared to treatment K0 (control). Treatment of K2 (20 ppm) obtained an average of 4.27 and did not show significantly different results compared to treatment of $\mathrm{K} 0$ (control) and $\mathrm{K} 3$ $(30 \mathrm{ppm})$. Growth regulators in the right concentration will work well, but on the other hand, if given in the wrong concentration, it will inhibit the growth of stem diameter. Each type of plant has a different response to the provision of growth regulators in type and concentration (11).

\section{Number of leaves}

The number of leaves are counted to determine the vegetative growth of the plant. The number of leaves can be counted when the leaves are fully opened. Leaves are plant organs used to synthesize food.

The results of the ANOVA test analysis at a 5\% level in a single treatment, namely the kinetin concentration, gave significant results on the parameter of the number of leaves. This was presumably because the function of cytokinins, among others, is to stimulate the growth of lateral shoots and stimulate morphogenesis. In contrast, the treatment interval of kinetin application and the interaction between the two treatments did not have a significant effect. Sawan et al. (12) explained that the application of exogenous growth regulators in plants could work actively depending on the application speed, application time and the stage of plant development at the time of application. After the DMRT difference test at 5\% level was carried out in table 3 , the best results were obtained on the leaf number parameter, was the $\mathrm{K} 3$ treatment (30 ppm), the average result was 44.56 . It was significantly different when compared to the K0 treatment (control) with an average of 32,89. Following Naeem et al. (5)'s research, the application of kinetin increased the number of dark green leaves. This increase may be due to cell division and increased meristem activity promoted by growth hormone. Mukherjee and Kumar (13) added that there were significant increases after kinetin application in the number of leaves, number of branches, and leaf area in 
previous studies. During the cell expansion phase, cytokinins help stimulate cell expansion and differentiation. As a result, the addition of cytokinins can produce an increase in leaf and rosette size, which is triggered by a higher rate of cell expansion, which results in higher biomass. Treatment K1 (10 ppm) obtained an average result of 36.11 , and treatment $\mathrm{K} 2$ (20 ppm) obtained an average result of 38.67. The two treatments were not significantly different when compared to the $\mathrm{K} 0$ treatment (control). The indirect effect of kinetin was thought to be due to inaccurate kinetin concentrations. Yunus et al. (14) stated that several factors could determine the success of the application of growth regulators, including the concentration used, the method of administration, the time of administration and the combination of growth regulators used.

\section{Number of branches}

Observation of the number of branches in this study is an essential variable because flowers will form on plant branches. The appearance of flowers is significant for propagation, especially in plants that are usually propagated sexually, such as Daun duduk.

The 5\% ANOVA analysis test results showed that a single treatment kinetin concentration significantly affects the growth of Daun duduk branches, then the DMRT difference test was carried out at the 5\% level. Table 4 showed that the treatment with the highest results, namely the $\mathrm{K} 3$ treatment (30 $\mathrm{ppm}$ ), obtained an average of 16.44 , significantly different compared to treatment K0 (control) which obtained an average of 9.89. This was presumably because growth regulators of cytokinins influence the growth of plant branches. Lakit (1996) in Darmanti et al. (15) stated that cytokinin hormones have an essential role in branch formation because the cytokinins found at the root tips will be transported through the xylem to the top of the plant. Cytokinins play a role in promoting shoot branching by activating the axillary buds. Sari and Tatik (16) added that in previous research, treatment of 30 ppm kinetin concentration could increase the number of chrysanthemum mother plant shoots compared to treatment without kinetin administration. Kieber and Eric (17) stated that cytokines' characteristics play a role in cell division and control of meristem activity, then the cells that divide will develop into shoots, branches and leaves. The results of observations on $\mathrm{K} 1(10 \mathrm{ppm})$ and $\mathrm{K} 2(20 \mathrm{ppm})$ treatments obtained the same average values of 12.67, indicating that it was not significantly different when compared to K0 treatment (control). When compared to K3 treatment (30 ppm), however, it showed significantly different results. The response of plants to growth regulators depends on the type, concentration, plant genotype and phases of plant physiology (1).

\section{Dry stover}

Dry stover is a growth parameter that can be used to measure plant growth along with all the events it has experienced. Dry weight is obtained by reducing water content, and the metabolic process has stopped until it reaches a constant weight. Solichatun et al. (18) stated that the size of growth is net weight. About $90 \%$ of the dry matter content of plants is the accumulation of material resulting from the photosynthesis process.

The results of the ANOVA test analysis at a 5\% level showed that the kinetin concentration treatment has a significant effect on the dry stover parameter of Daun duduk, then continued with 5\% DMRT difference test. Table 5 showed that the treatment with the highest yield of dry stover parameters, was the $\mathrm{K} 3$ treatment (30 ppm), with an average of 9.78, which was significantly different from the $\mathrm{K} 0$ treatment (control) with an average of 5.30. This was because the treatment of $30 \mathrm{ppm}$ kinetin concentration in most of the previous parameters was the treatment with the best growth results and undoubtedly contributed to plant weight. According to Larcher (1975) in Suntoro et al. (19), plant dry weight was obtained from an accumulation of coassimilation ${ }_{2}$ during plant growth and development. The accumulation of dry matter and increase in wet weight are considered as the growth of a plant. So, the better the plant growth, the more dry weight will increase. Harjadi (1993) and Hopskin (1990) in Sartika and Djoko (20) added that the increase in plant size or dry weight reflects the increase in protoplasm that occurs due to the increased of size and number of cells. Moringa leaf extract and cytokinins were applied to the leaves, and both treatments significantly increased the biomass of tomato plant shoots. K2 treatment (20 ppm) obtained an average of 7.45, where the treatment was not significantly different when compared with K0 treatment (control) and K3 treatment (30 ppm). 
Meanwhile, K1 treatment (10 ppm) obtained an average of 6.62 , which was not significantly different from K0 (control). This was presumably because the application of growth regulators with inappropriate concentrations will not have a natural effect and can even inhibit the growth and development. The K0 treatment (control) gave the lowest yield on dry stover parameters, presumably because there was no addition of growth regulators to the treatment, so the growth was not as good as the other treatments. Following the statement of Trisna et al. (10), that some growth regulators can function to stimulate plant growth and development under normal conditions, while plants that do not use growth regulators will have a slower growth rate.

\section{Number of roots}

Roots are vegetative organs that support plant growth which is very important in obtaining food. According to Irwan (2015) in Putri et al. (9), roots function as a means of absorption or absorption of nutrients from the soil and as a place to store food reserves.

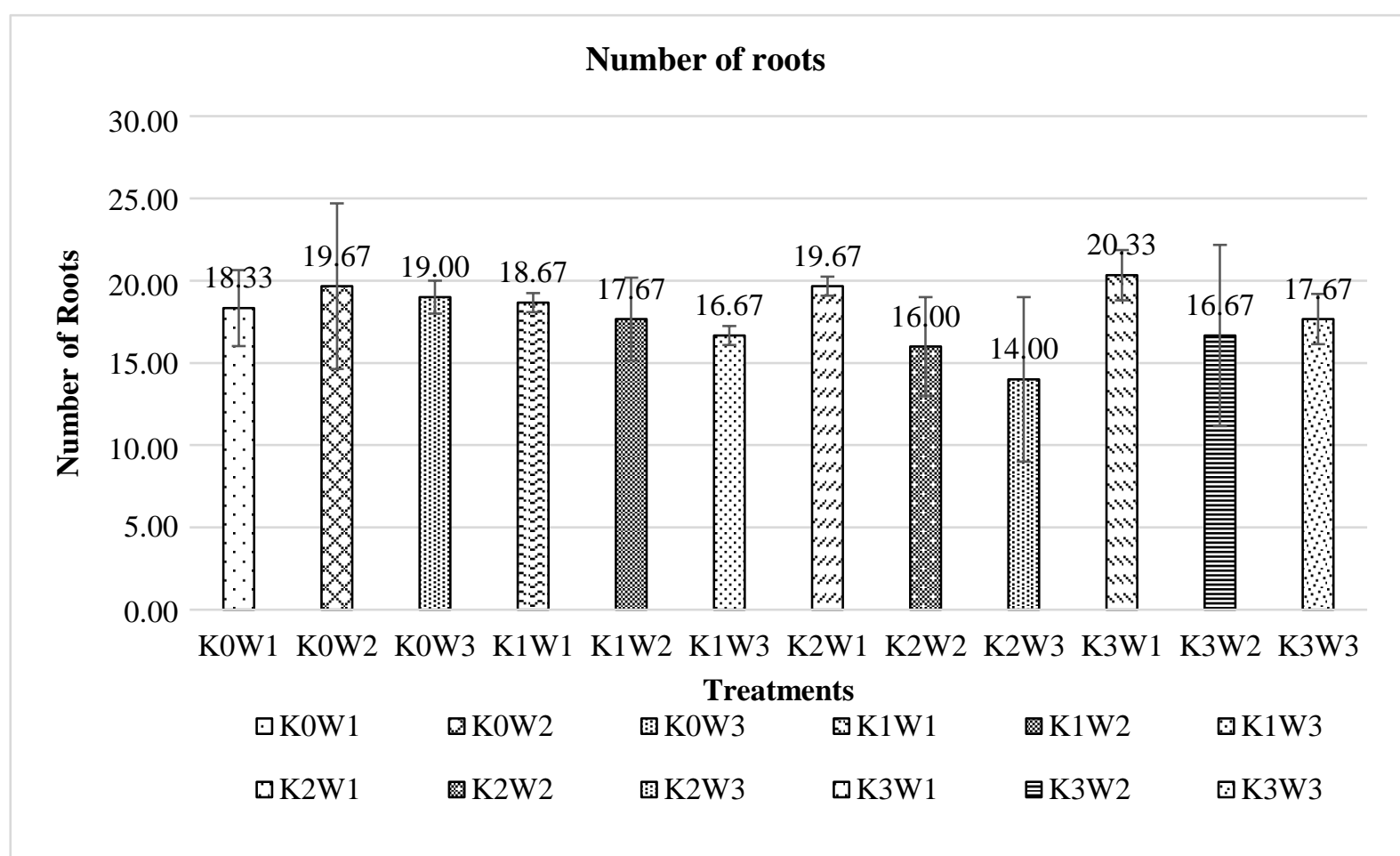

Figure 1. Effect of Concentration and Time Interval of Kinetin on the Daun Duduk Number of Roots. K0 (control, K1 (10 ppm, K2 (20 ppm), K3 (30 ppm), W1 (once every three months), W2 (once every 1.5 months) and W3 (once a month)

The results of the ANOVA analysis at a 5\% level showed that all treatments, both kinetin concentration, kinetin administration time interval and the interaction between the two, did not have a significant effect on the growth of the number of sitting leaf roots. The difference in kinetin concentration does not affect the increase in the number of roots. This is presumably because the growth regulators of cytokinins are more focused on stimulating the vegetative growth of the canopy, not on root growth. According to Wybouw and Bert (6), cytokinins harm root initiation. Lateral and auxin accumulation. Fastest callus initiation speed, namely on media with the addition of a growth regulator 2,4-D $1 \mathrm{ppm}$ and kinetin $0.1 \mathrm{ppm}$, where the kinetin concentration is lower than the 2,4-D concentration. This is because 2,4-D is a type of auxin that can cause root growth, while kinetin can stimulate cell division in plant tissue.

The number of roots was not consistent among all treatments in this study, and this was presumably because the endogenous auxin contained in the plant was sufficient to support root growth. Without the provision of growth regulators, each plant naturally produces growth regulators in its body, such as auxins. Asra et al. (21) stated that auxins could be found in meristematic areas such as stem tips, root tips, flower buds (at the time of flower formation) and seed embryos. Then auxin will be translocated towards the bottom of the stem to stimulate plant 
root growth. According to Wattimena (1991) in Indriani et al. (11), root growth only requires auxins without cytokinins or cytokinins in low concentrations. Putriana et al. (22) added that kinetin is a growth regulator for the cytokinin group, which generally has an organogenetic effect on inducing shoot growth so that the response to root growth is not affected.

\section{Roots length}

Roots are planted vegetative organs that can grow and develop if growth-supporting factors such as sunlight, water, space to grow and nutrient needs are met. Ai and Patricia (23) explained that long roots would be able to absorb more water.

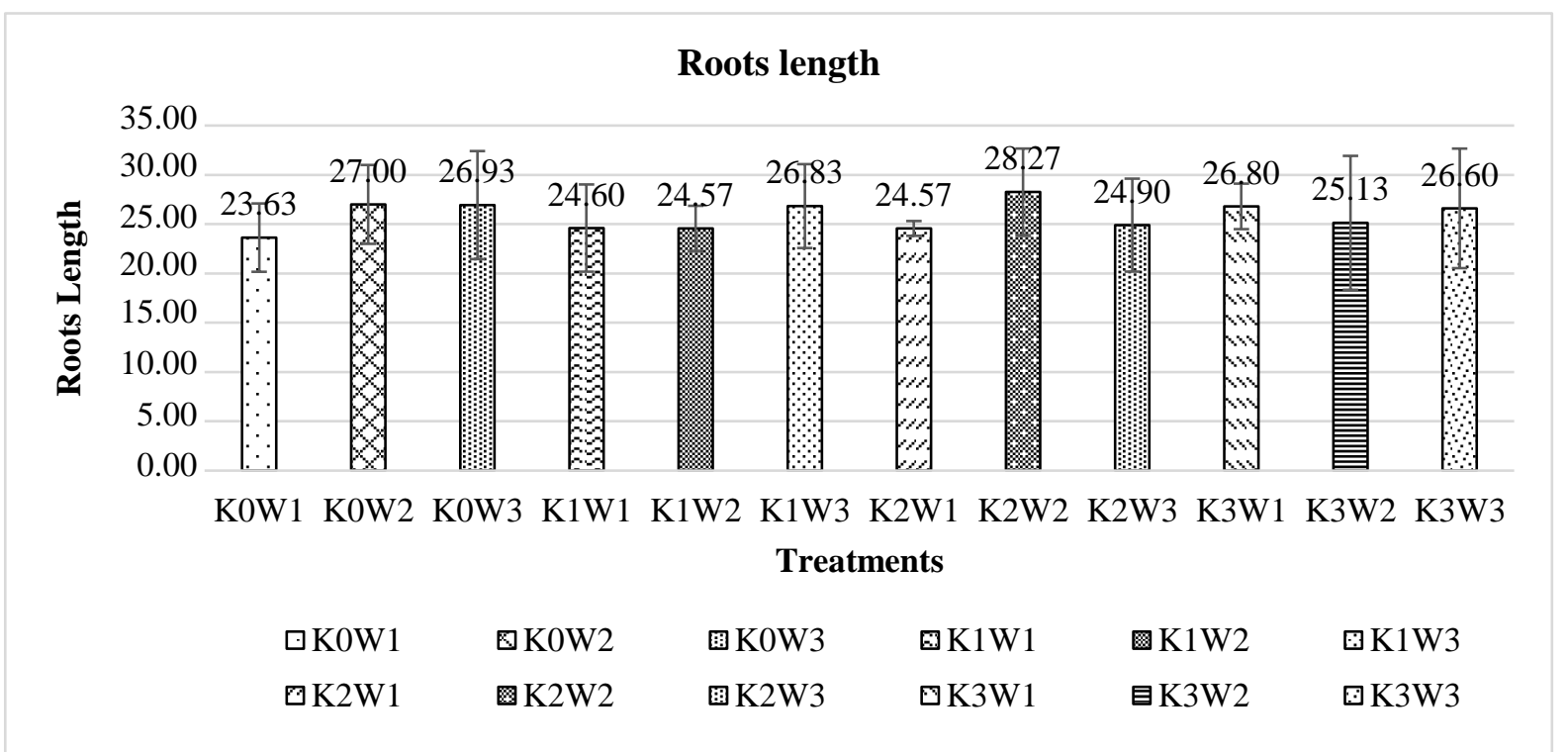

Figure 2. Effect of Concentration and Time Interval of Kinetin on the Daun Duduk Length of Roots. K0 (control, K1 (10 ppm, K2 (20 ppm), K3 (30 ppm), W1 (once every three months), W2 (once every 1.5 months) and W3 (once a month)

The results of the ANOVA analysis at a $5 \%$ level showed that all treatments in this study, both kinetin concentration, kinetin administration time interval and the combination of the two, did not have a significant effect on Daun duduk roots length. This is thought to be because, according to Angelina et al. (24), cytokinins are not growth regulators that focus on affecting root growth but affect various physiological processes in plants, especially in promoting cell division. Root length is influenced by the media planting media, such as soil density in the growing medium and limited root space. The higher the soil density and the lower the volume of the planting medium, the longer roots will be less. This is because the plant roots will continue to look for water and nutrients in the soil. Root length growth was almost uniform across all treatments because this study using polybags of the same size. Marzukoh et al. (25), in their research, said that planting tomatoes in polybags will cause the space to grow roots to be more limited, so that root growth and development are also limited. The volume of soil in polybags also causes the volume of available water to be limited, so root growth is not optimal.

Endogenous auxins play a role in root length parameters. Auxins that are synthesized near the shoot meristem will be translocated to the bottom of the stem. Asra et al. (21) explained that when translocated to all parts of the plant, each part gets a different amount of auxin levels. This causes the response to plant growth, such as root length, to vary from plant to plant. Gunawan (1992) in Aprilyani (26) added that the balance between exogenous and endogenous growth regulators can spur growth and development. Suryanto (2005), in Wijayanto and Iftitah (27), stateed that the physiological concept of root growth is based on the morphogenetic balance between roots and plant canopy.

\section{Fresh stover}

Fresh stover was obtained by weighing the plants at the end of the observation. According to Sitompul and Guritno (1995) in Sartika and Djoko (20), fresh stover is influenced by water in cells, metabolism, and moisture conditions of a plant. 




\section{Conclusion}

1. The concentration of $30 \mathrm{ppm}$ kinetin alone can increase the growth of Daun duduk on plant height parameters obtained by an average of 43.29 , and stem diameter obtained an average of 4.61 . The number of leaves obtained an average of 44.56, the number of branches obtained an average 16.44 and dried stover obtained an average of 9.78. In contrast, the time interval of offering kinetin alone did not stimulate the growth of sitting leaves in all experimental parameters.

2. The most effective kinetin concentration in increasing the growth of Daun duduk was 30 $\mathrm{ppm}$, while the time interval for offering kinetin has not got the right time.

3. The interaction between the concentration and the time interval of kinetin administration did not affect all the experimental parameters.

\section{Acknowledgements}

The author would like to thank B2P2TOOT, Tawangmangu, Karanganyar for helping to provide the Daun duduk planting material for this research.

\section{Conflict of Interest}

All authors declare no conflicts of interest in this section.

\section{References}

1. Ismail I. Faktor Yang Mempengaruhi Keputusan Masyarakat Memilih Obat Tradisional Di Gampong Lam Ujong. Idea Nurs J. 2015;6(1):7-14.

2. Badan Pusat Statistik. Ekspor tanaman obat, aromatik, dan rempah-rempah menurut negara tujuan utama 2012-2019. Badan Pusat Statistik. Jakarta; 2019.

3. Salim Z, Ernawati M. Info komoditi 
tanaman obat. Jakarta; 2017.

4. Mirza M, Amanah S, Sadono D. Tingkat kedinamisan kelompok wanita tani dalam mendukung keberlanjutan usaha tanaman obat keluarga di Kabupaten Bogor, Jawa Barat. J Penyul. 2017;13(2):181-93.

5. Naeem M, Bhatti I, Ahmad RH, Ashraf MY. Effect of some growth hormones (GA3, IAA and kinetin) on the morphology and early or delayed initiation of bud of lentil (Lens culinaris medik). Pakistan J Bot. 2004;36(4):8019.

6. Wybouw B, De Rybel B. Cytokinin - A developing story. Trends Plant Sci. 2019;24(2):177-85.

7. Haryadi D, Yetti H, Yoseva S. Pengaruh pemberian beberapa jenis pupuk terhadap pertumbuhan dan produksi tanaman kailan (Brassica alboglabra L.). J Online Mhs Fak Pertan Univ Riau. 2015;2(2):110.

8. Bakar M, Jeany M, Deanne K, Sofia D. Penggunaan bap dan kinetin pada induksi tunas dari protocorm anggrek dendrobium (Dendrobium sp.) pada kultur in vitro. Cocos. 2016;7(4).

9. Putri BF, Fakhrurrozi Y, Rahayu S. Pengaruh perbedaan jenis media tanam terhadap pertumbuhan setek hoya coronaria berbunga kuning dari kawasan hutan kerangas air anyir, Bangka. Ekotonia J Penelit Biol Bot Zool dan Mikrobiol. 2018;3(1):20-8.

10. Trisna N, Umar H, Irmasari. Pengaruh berbagai jenis zat pengatur tumbuh terhadap pertumbuhan stump jati (Tectona grandis L.F). War Rimba. 2013;1(1):1-6.

11. Indriani M, Manuhara S, Utami E. Pengaruh zat pengatur tumbuh 2,4-D, kinetin dan bap terhadap pertumbuhan dan perkembangan ekstrak daun sambung nyawa (Gynura procumbens Merr.). Surabaya: Universitas Airlangga; 2016.

12. Sawan Z, Mohamed A, Sakr R, Tarrad A. Effect of kinetin concentration and methods of application on seed germination, yield components, yield and fiber properties of the Egyptian cotton (Gossypium barbadense). Environ Exp Bot. 2000;44(1):59-68.

13. Mukherjee D, Kumar R. Kinetin regulates plant growth and biochemical changes during maturation and senescence of leaves, flowers, and pods of Cajanus cajan L. Biol Plant. 2007;51(1):80-5.

14. Yunus A, Muji R, Samanhudi, Pujiasmanto B, Himawan J. Respon kunir putih (Kaempferia rotunda) terhadap pemberian iba dan bap pada kultur in vitro. Agrosains. 2016;18(2):44-9.

15. Darmanti S, Setiari N, Romawati TD. Perlakuan defoliasi untuk meningkatkan pembentukan dan pertumbuhan cabang lateral jarak pagar (Jatropha curcas). Anat Fisiol. 2008;16(2):13-9.

16. Sari A, Wardiyati T. Pengaruh pemberian kinetin dan pgpr (plant growth promoting rhizobacteria) terhadap pertumbuhan mother plant krisan (Chrysanthemum sp.). J Produksi Tanam. 2018;6(3):488-94.

17. Kieber JJ, Eric Schaller G. The perception of cytokinin: A Story 50 years in the making. Plant Physiol. 2010;154(2):48792.

18. Solichatun E, Mudyantini W. Pengaruh ketersediaan air terhadap pertumbuhan dan kandungan bahan aktif saponin tanaman ginseng jawa (Talinum paniculatum Gaertn.). Biofarmasi. 2005;3(2):47-51.

19. Suntoro, Syamsiyah J, Rahina W. Ketersediaan dan serapan Ca pada kacang tanah di tanah alfisols yang diberi abu vulkanik kelud dan pupuk kandang. Agrosains J Penelit Agron. 2017;19(2):51-7.

20. Sartika D, Djoko S. Pengaruh kombinasi zat pengatur tumbuh (2,4 D dan kinetin) terhadap pertumbuhan dan kandungan metabolit sekunder pada kalus Phaleria macrocarpa (Scheff.) Boerl.). J Tumbuh Obat Indones. 2012;5(1):53-62.

21. Asra R, Ririn A, Mariana S. Hormon tumbuhan. Jakarta: UKI Press; 2020.

22. Putriana, Gusmiaty, Restu M, Musriati, Aida N. Respon kinetin dan tipe eksplan jabon merah (Antocephalus macrophyllus (Roxb.) Havil) secara in vitro. J Biol Makassar. 2019;4(1):48-57.

23. Ai N, Torey P. Karakter morfologi akar sebagai indikator kekurangan air pada tanaman (Root morphological characters as water-deficit indicators in plants). $\mathbf{J}$ Bios Logos. 2013;3(1):31-9.

24. Angelina N, Luthfi A, Lollie A. Pengaruh zat pengatur tumbuh terhadap induksi akar (Rhizogenesis) pada tanaman bangun-bangun (Plectranthus amboinicus 
(Lour.) Spreng) secara in vitro. $\mathbf{J}$ Agroekoteknologi FP USU. 2017;82:644-9.

25. Marzukoh RU, Sakya AT, Rahayu M. Pengaruh volume pemberian air terhadap pertumbuhan tiga varietas tomat (Lycopersicum esculentum Mill). J Agrosains. 2013;15(1):12-6.

26. Apriliyani N, Mukarlina, Rizalinda. Pertumbuhan stek batang sirih merah (Piper crocatum Ruiz.) setelah perendaman dengan ekstrak bawang merah (Allium cepa L.) dan air kelapa (Cocos nucifera L.). J Protobiont. 2018;7(3):54-61.

27. Wijayanto N, Rhahmi I. Panjang dan kedalaman akar lateral jabon (Anthocephalus cadamba (Roxb.) Miq.) di Desa Cibening, Kecamatan Pamijahan, Kabupaten Bogor, Jawa Barat. J Silvikultur Trop. 2013;4(1):23-9. 